Retraction

\title{
Retracted: DNA Binding and Photocleavage Studies of Cobalt(III) Polypyridine Complexes: $\left[\mathrm{Co}(\mathrm{en})_{2} \mathrm{PIP}\right]^{3+},\left[\mathrm{Co}(\mathrm{en})_{2} \mathrm{IP}\right]^{3+}$, and $\left[\mathrm{Co}(\mathrm{en})_{2} \text { phen-dione }\right]^{3+}$
}

\author{
Bioinorganic Chemistry and Applications
}

Received 6 August 2020; Accepted 6 August 2020; Published 19 January 2021

Copyright () 2021 Bioinorganic Chemistry and Applications. This is an open access article distributed under the Creative Commons Attribution License, which permits unrestricted use, distribution, and reproduction in any medium, provided the original work is properly cited.

Bioinorganic Chemistry and Applications has retracted the article titled "DNA Binding and Photocleavage Studies of Cobalt(III) Polypyridine Complexes: $\left[\mathrm{Co}(\mathrm{en})_{2} \mathrm{PIP}\right]^{3+}$, $\left[\mathrm{Co}(\mathrm{en})_{2} \mathrm{IP}\right]^{3+}$, and $\left[\mathrm{Co}(\mathrm{en})_{2} \text { phen-dione }\right]^{3+»}[1]$.

This article has been retracted as it is essentially identical in title and technical content with a previously published paper in Polyhedron. The earlier publication is "DNA binding and cleavage properties of certain ethylenediamin cobalt(III) of modified 1,10-phenanthrolines," Penumaka Nagababu and S. Satyanarayana, Polyhedron, Volume 26, Issue 8, Pages 1686-1692.

\section{References}

[1] P. Nagababu and S. Satyanarayana, "DNA Binding and Photocleavage Studies of Cobalt(III) Polypyridine Complexes: $\left[\mathrm{Co}(\mathrm{en})_{2} \mathrm{PIP}\right]^{3+},\left[\mathrm{Co}(\mathrm{en})_{2} \mathrm{IP}\right]^{3+}$, and $\left[\mathrm{Co}(\mathrm{en})_{2} \text { phen-dione }\right]^{3+}, "$ Bioinorganic Chemistry and Applications, vol. 2007, Article ID 54562, 8 pages, 2007. 